\title{
Performance of Native and Copper-Ethanolamine-Treated Wood Exposed to Seawater at Port of Koper, Slovenia
}

\section{Rezultati izlaganja nezaštićenog drva i drva zaštićenog bakar-etanolaminom utjecaju morske vode u luci Koper, Slovenija}

\author{
Original scientific paper • Izvorni znanstveni rad \\ Received-prispjelo: 26. 11. 2012. \\ Accepted-prihvaćeno: 6. 11. 2013. \\ UDK: $630 * 841.523 ; 630 * .845 .1$ \\ doi:10.5552/drind.2013.1251
}

\begin{abstract}
The application of wood in seawater is one of the most challenging. Impregnated wood is exposed to leaching and to various marine borers, Limnoria sp. and Teredo sp. being the most important ones. The present research investigated the durability of pine wood impregnated with copper-amine based preservative solution (Silvanolin) of different concentrations exposed to the seawater according to EN 275 standard. Performance of Silvanolin treated wood was compared to the performance of reference wood (Quercus sp., Castanea sativa, Larix decidua). After 10, 18 and 32 months of exposure, specimens were removed and assessed. The results show clearly that the reference wood species were completely degraded after 10 months of exposure. On the other hand, it became evident that Silvanolin prolonged the service life of wood exposed to the sea. The specimens impregnated with the lowest concentration of preservative solution $\left(c_{\mathrm{Cu}}=0.31 \%\right)$ were slightly decayed. The specimens, impregnated with higher concentrations of copper $\left(c_{C u}>0.31 \%\right)$, showed almost no defects after expsore to marine borers.
\end{abstract}

Keywords: marine borers, Limnoria sp., Teredo sp., EN 275, cooper based preservative, Adriatic Sea

SAŽETAK • Primjena drva u morskoj vodi jedna je od najizazovnijih primjena drva. Impregnirano drvo izloženo je ispiranju te raznim morskim štetnicima, pri čemu su Limnoria sp. i Teredo sp. među najštetnijima. U radu je prikazano istraživanje trajnosti borova drva impregniranoga zaštitnom otopinom na bazi bakar-amina (Silvanolin) različitih koncentracija i izloženoga morskoj vodi prema normi EN 275. Izgled drva zaštićenog Silvanolinom uspoređen je s izgledom referentnoga drvnog materijala (Quercus sp., Castanea sativa, Larix decidue). Nakon 10 , 18 i 32 mjeseca izlaganja morskoj vodi, uzorci su izvađeni te ocijenjeni. Iz dobivenih se rezultata može jasno vidjeti da su uzorci referentnog drva nakon 10 mjeseci bili potpuno razgrađeni. Nasuprot tome, pokazalo se da Silvanolin produžuje vijek trajanja drva u moru. Uzorci impregnirani otopinom zaštitnog sredstva najmanje koncentracije $\left(c_{C u}=0,31 \%\right)$ blago su istrunuli. Uzorci impregnirani otopinom zaštitnog sredstva s većom koncentracijom bakra $\left(c_{C u}>0,31 \%\right)$ nisu pokazali gotovo nikakva oštećenja nakon izlaganja morskim štetnicima.

Ključne riječi: morski štetnici, Limnoria sp., Teredo sp., EN 275, zaštitna sredstva na bazi bakra, Jadransko more

\footnotetext{
${ }^{1}$ Author is professor at University of Ljubljana, Biotechnical Faculty, Ljubljana, Slovenia. ${ }^{2}$ Author is employee of the company Montažna gradnja Tadej Zimic s.p., Ljubljna - Šentvid, Slovenia.

${ }^{1}$ Autor je profesor Biotehničkog fakulteta Sveučilišta u Ljubljani, Ljubljana, Slovenija. ${ }^{2}$ Autor je zaposlenik tvrtke Montažna gradnja Tadej Zimic s.p., Ljubljana - Šentvid, Slovenija.
} 


\section{INTRODUCTION}

\section{UVOD}

Wooden material is widely used in the sea due to its abundance that means renewable material, elastic properties, low production costs and easy plantation. Wood in sea water applications is exposed to a variety of physical factors and wood-decaying organisms. They use wood as food or as shelter. Besides erosion, wood in sea water applications is primarily endangered by Teredo sp., Limnoria sp. and Pholades (Sen et al., 2010). These organisms cause failure of unprotected wood in rather short time between one and two years (Cragg, 1989; 1999; Westin et al., 2004; Lesar and Humar, 2011). In order to protect wood against degrading organism in sea water applications, it must be impregnated with effective biocides. In the past, mainly chromated copper arsenate (CCA) or/and creosote was used for impregnation (Eaton and Hale, 1993). Double treatment (two-step impregnation process - the first step is impregnation with CCA according to the full cell process, dry CCA treated wood is impregnated with creosote according to the full or empty cell process) was the most effective (Wilkinson, 1979; Cragg, 1989). During the implementation of the Biocidal Products Directive (98/8/EC, 1998) in 2006, the use of chromium based wood preservatives was considerably limited or even banned in some EU countries. On the other hand, the use of creosote was only allowed in class 3 applications (2011/71/EU, 2011). In spite of legislation issues, copper based biocides still belong to the most important active ingredients in wood preservatives in Europe. The main reason for their wide use is a good ratio between efficacy and toxicity, and the fact that most of the competitive products have been banned. Therefore, copper is still allowed to be used in all classes, including use class 5 (sea water applications) (EN 335, 2006). In order to meet legislation requirements, chromium compounds in wood preservatives were replaced with amines, predominately ethanolamine. Unfortunately, fixation of copper-ethanolamine based wood preservatives is not as efficient as the fixation of copper-chromium ones (Humar et al., 2001; Cooper and Ung, 2009). Additionally, public perception of the use of biocides is sometimes negative (Despot et al., 2008). Therefore, biocidal solutions are replaced with biocide free alternatives like naturally durable wood species (Connell, 2004). The aim of this study was to elucidate the performance of copperamine treated wood in the northern Adriatic Sea and compare it to the performance of naturally durable and reference wood species. There are few reports about the presence of marine borers in the Northern Adriatic. As wood is endangered by marine borers, wood has not been traditionally used for sea water applications. So, to the best of our knowledge, this is the first report regarding the performance of wood in sea water applications in Northern Adriatic.

\section{MATERIALS AND METHODS} 2. MATERIJALI I METODE

Testing was performed according to the standard procedure described in the European Standard EN 275 (2004). The two goals of this experiment were: (1) to determine the performance of naturally durable and reference wood species; and (2) to determine the performance of wood impregnated with commercial copper-ethanolamine based aqueous solution (Silvanolin, Silvaprodukt) in sea water conditions (use class 5).

To determine the performance of naturally durable species, specimens $(200 \mathrm{~mm} \times 75 \mathrm{~mm} \times 25 \mathrm{~mm})$ made of European oak (Quercus sp.), European larch (Larix decidua) and sweet chestnut (Castanea sativa) heartwood were prepared. In parallel Scots pine (Pinus sylvestris) sapwood specimens of the same dimensions were prepared. They were vacuum-pressure impregnated according to the full cell procedure (30 min vacuum at $10 \mathrm{kPa} ; 3 \mathrm{~h}$ pressure at $900 \mathrm{kPa} ; 15$ min vacuum at $20 \mathrm{kPa}$ ) with copper-ethanolamine solution of five different concentrations (Table 1). Commercial solutions consisting of copper hydroxide-carbonate, ethanolamine, quaternary ammonium compound, boric acid and octanoic acid were used. Detailed composition of preservative solution is available in the patent of $\mathrm{Hu}-$ mar and Pohleven (2008). Ratios between all active ingredients were the same in all treating solutions, only the concentration varied. For comparison, specimens were impregnated with reference copper and chromium based solution, as prescribed by the standard EN 275 (2004). For each treatment/wood species, 10 specimens were prepared. After impregnation, the uptake of preservative solution was determined gravimetrically. Retention was determined through comparison of the oven dry masses before and after impregnation. Retention shows the quantity of wood preservatives introduced into wood, excluding water.

After a month of conditioning at temperature of $20{ }^{\circ} \mathrm{C}$ and $70 \%$ relative humidity, specimens were mounted to a specially designed stand and exposed to seawater in the Port of Koper, Slovenia, at the depth of $6 \mathrm{~m}$. The average sea temperature in Koper is $15.8^{\circ} \mathrm{C}$, minimum temperature in February is $8{ }^{\circ} \mathrm{C}$, and maximum in August is $24{ }^{\circ} \mathrm{C}$. The average salinity is between $37 \%$ and $38 \%$, and can reach $35 \%$ in summer (Rejec Brancelj, 2011). Impregnated pine wood specimens together with respective controls (non-impregnated pine wood specimens) were exposed to seawater on Oct. 10, 2009. The assessment of the specimens was performed after 18 months and 32 months. Naturally, durable and reference specimens were exposed on June 22, 2011 and assessed after 10 months of exposure. Scots pine wood specimens were used as control for both experiments. Natural durable specimens were exposed in the second step, due to limited space in test rack. As they were exposed almost throughout the whole year, the time of exposure should not have a significant impact on the performance.

The assessment was performed visually. First, surfaces of the specimens were mechanically cleaned 
of algae and other fouling organisms. Then specimens were split with a band-saw, and the presence of bore holes in the interior of the specimens was visually examined and valuated with marks: 0 (no destruction), 1 (little destruction), 2 (moderate destruction), 3 (violent destruction) and 4 (severe damage, tunnels cover more than $50 \%$ of the specimens surface), according to the standard EN 275. The assessment was performed separately for Limnoria sp. and separately for Teredo sp. damages. The standard EN 275 prescribes the assessment to be performed by X-ray scanning. As there was no such device available in the offshore territory of the Port of Koper, destructive testing was performed. Therefore, more specimens were exposed in parallel, enabling destructive evaluation. The evaluated specimens were destroyed, while parallel specimens remained in the sea for further testing.

\section{RESULTS AND DISCUSSION}

\section{REZULTATI I RASPRAVA}

In the present research, Scots pine sapwood was used for impregnation with copper based wood preservatives. Pine sapwood is very easy to impregnate (EN 350-1, 1994), which can be seen in high uptakes of preservative solutions. All impregnated specimens retained between $421 \mathrm{~kg} / \mathrm{m}^{3}$ (Silvanolin E) and $453 \mathrm{~kg}$ / $\mathrm{m}^{3}$ (Copper-chromium based solution) of preservative solutions (Table 1), indicating that specimens were completely impregnated with wood preservatives. Differences between preservatives were insignificant (Table 1). As expected, more prominent differences were observed with retention. The ratio between the lowest and the highest retention was 1:13. Furthermore, retention data clearly indicates that even the preservative solution of the highest concentration was able to penetrate the wood to the same depth as the preservative solution of the lowest concentration.

All specimens were completely overgrown with different fouling organisms like algae and mussels, after 18 months of exposure (Figure 1). This clearly indicates the biodiversity of the northern part of the Adriatic Sea. After short-term exposure, the interior of all control specimens were completely destroyed, and on the other hand, the surface (outer $1 \mathrm{~mm}$ to $2 \mathrm{~mm}$ shell) of the specimens remained almost intact. Detailed analysis of the damages revealed that boreholes were made by Teredo sp. as well as by Limnoria sp. Similar damages of untreated Scots pine were determined after exposure in the North Sea (Westin et al., 2004; Larsson-Brelid and Westin, 2010), Mediterranean Sea in Turkey (Sen et al., 2010) and southern Portuguese coast (Williams et al., 2007). This comparison revealed that the chosen field test site (Port Koper) is biologically active. According to the statements of Kiersgaard (2011), Limnoria and Teredo species prefer warmer locations, meaning that the Adriatic Sea should offer better conditions than the North Sea. However, it should be taken into consideration that these tests are preliminary, and therefore huge variations are possible depending on years of exposure. Other factors affecting the development of Teredo and Limnoria are salinity and temperature. In rainy and cold weather, the development of Teredo species is considerably slowed down, as severe late summer and autumn rainfalls reduce the salinity of the water.

Next to the pine sapwood specimens, specimens of heartwood of naturally durable and reference wood species were exposed. Sapwood of Scots pine was completely deteriorated after 10 months of exposure. Similar to pine sapwood, non-treated specimens of heartwood of European oak, sweet chestnut and European larch were completely deteriorated as well (Table 2, Figure 2). Damages caused by Teredo sp. were more frequent and more visible than damages caused by Limnoria sp. This result clearly indicates that domestic wood species from central Europe, despite their good natural durability, do not offer sufficient resistance against marine boring organisms (when used in class 5 applications without good biocidal protection). Data from the literature reveal that conditions for wood in sea water applications in the northern part of the Adriatic Sea are even more severe than the ones in the southern Mediterranean. For example, Sen and coworkers (2010) reported that oak and sweet chestnut perform better than pine sapwood in the Turkish part of

Table 1 Composition, uptake and retention of preservative solutions

Tablica 1. Sastav, upijanje i zadržavanje otopine zaštitnog sredstva

\begin{tabular}{|l|c|c|c|}
\hline $\begin{array}{c}\text { Preservative solution } \\
\text { Otopina zaštitnog sredstva }\end{array}$ & $\begin{array}{c}\mathbf{c}_{\mathrm{Cu} \text { in preservative solution }} \\
\text { Koncentracija bakra } u \\
\text { zaštitnom sredstvu } \\
\%\end{array}$ & $\begin{array}{c}\text { Uptake of preservative } \\
\text { solution } \\
\text { Opijanje otopine zaštitnog } \\
\text { sredstva } \\
\mathrm{kg} / \mathrm{m}^{3}\end{array}$ & $\begin{array}{c}\text { Retention } \\
\text { Zadržavanje } \\
\mathrm{kg} / \mathrm{m}^{3}\end{array}$ \\
\hline CC 1 & 1.2 & 453 & 5.4 \\
\hline CC 5 & 5.0 & 442 & 22.1 \\
\hline Silvanolin A & 0.31 & 447 & 19.0 \\
\hline Silvanolin B & 0.625 & 436 & 37.0 \\
\hline Silvanolin C & 1.25 & 437 & 74.1 \\
\hline Silvanolin D & 2.5 & 427 & 144.8 \\
\hline Silvanolin E & 4.0 & 421 & 230.1 \\
\hline
\end{tabular}




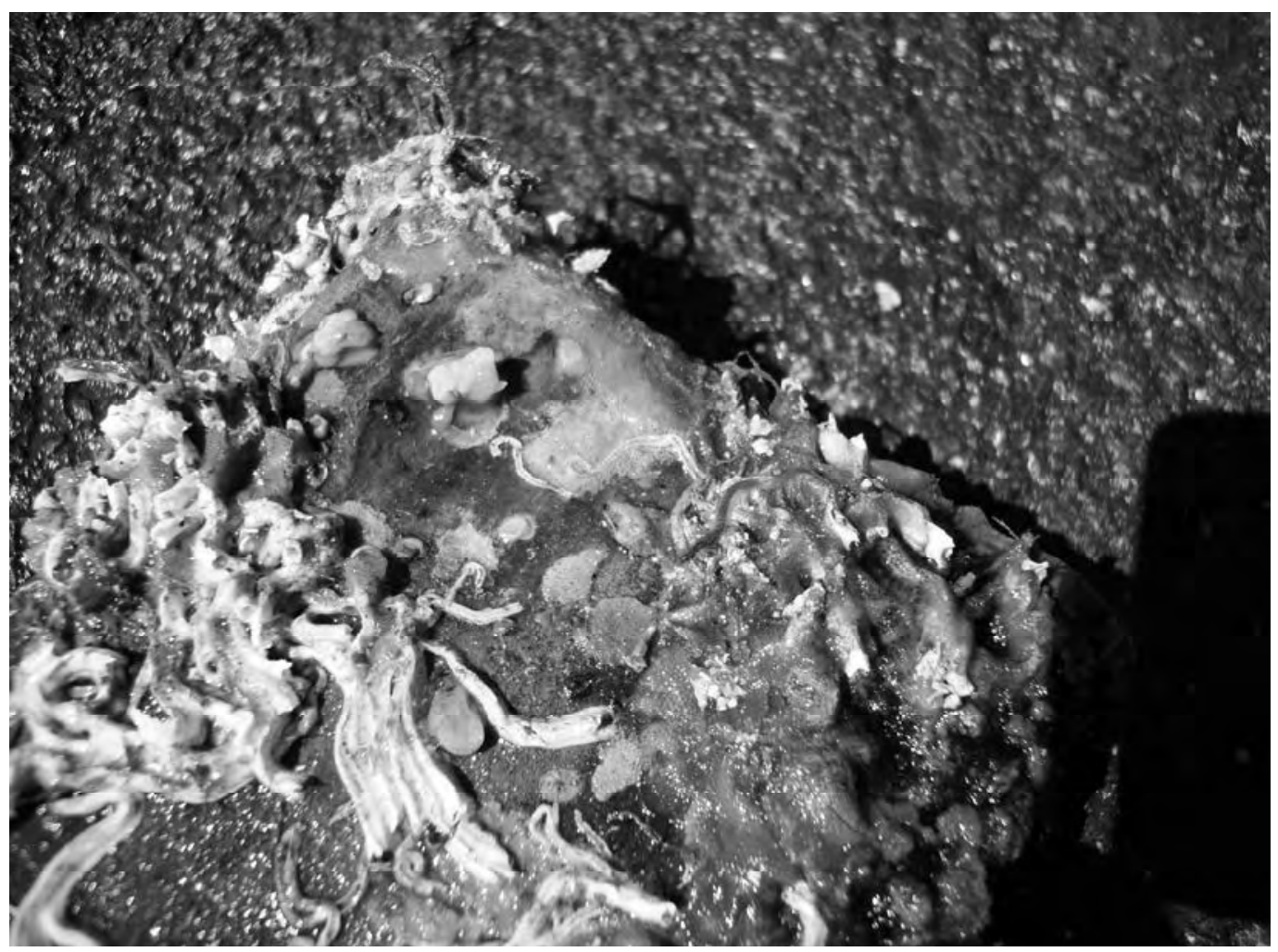

Figure 1 Visual appearance of specimens after 10 weeks of exposure in Adriatic Sea Slika 1. Izgled uzoraka nakon 10 dana izlaganja u Jadranskome moru

the Mediterranean Sea, and do not deteriorate as fast as in the Port of Koper.

Contrary to naturally durable wood species, Silvanolin treated wood performed much better, if sufficient retention has been applied. After 18 months of testing, there were no signs of damage in wood that retained at least $37 \mathrm{~kg} / \mathrm{m}^{3}$ of Silvanolin compounds (Silvanolin B; $\mathrm{c}_{\mathrm{Cu}}=0,625 \%$ ). On the other hand, 18 months was sufficient to see the first signs of deterioration in wood containing $19 \mathrm{~kg} / \mathrm{m}^{3}$ of copper-amine compounds (Silvanolin A; $\mathrm{c}_{\mathrm{Cu}}=0.31 \%$ ) (Figure 3). This deterioration continues, and after 32 months, this wood was almost completely degraded (Table 3). However, retention of $37 \mathrm{~kg} / \mathrm{m}^{3}$ of Silvanolin B was insufficient to prevent degradation for 32 months, as the first signs of degradation were noted. Therefore, higher concentrations have to be used to ensure proper protection against marine borers. The majority of the damage on copper treated wood was caused by Teredo sp. These results indirectly proved that copper remained in wood even after 32 months of exposure. During 18 months of exposure, control-scots pine wood specimens were completely deteriorated as well. This indicates the susceptibility of the material to and presence of active marine borers.

Reference material (CC1 and CC 5), impregnated with copper-chromium based solutions was protected at both reference concentrations (Table 3). Similar results are reported by Westin and co-workers (2004). They reported that the life cycle of specimens, impregnated with CCA target retention of $4 \mathrm{~kg} / \mathrm{m}^{3}$, is around 3.2 years, while specimens retaining $18 \mathrm{~kg} / \mathrm{m}^{3}$ of CCA

Table 2 Performance of different untreated wood species exposed to seawater for 10 months in the Port of Koper according to the EN 275 standard (2004)

Tablica 2. Ocjena izgleda različito zaštićenih uzoraka drva nakon 10 mjeseci izlaganja morskoj vodi u luci Koper; prema normi EN 275 (2004)

\begin{tabular}{|l|c|c|c|}
\hline \multirow{2}{*}{\begin{tabular}{c}
\multirow{2}{*}{$\begin{array}{c}\text { Wood species } \\
\text { Vrsta drva }\end{array}$} \\
\cline { 2 - 4 }
\end{tabular}} & \multicolumn{3}{|c|}{$\begin{array}{c}\text { Mean rating of deterioration after 10 months of exposure } \\
\text { Srednja ocjena propadanja uzoraka nakon 10 mjeseci izlaganja }\end{array}$} \\
\cline { 2 - 4 } $\begin{array}{c}\text { Teredo } \\
\text { (softwood) }\end{array}$ & 4 & Limnoria & Total / ukupno \\
\hline $\begin{array}{l}\text { Larix decidua } \\
\text { (heartwood) }\end{array}$ & 4 & 1.6 & 4 \\
\hline $\begin{array}{l}\text { Castanea sativa } \\
\text { (heartwood) }\end{array}$ & 3.75 & 3.8 & 4 \\
\hline $\begin{array}{l}\text { Quercus sp. } \\
\text { (heartwood) }\end{array}$ & 4 & 3.1 & 4 \\
\hline
\end{tabular}




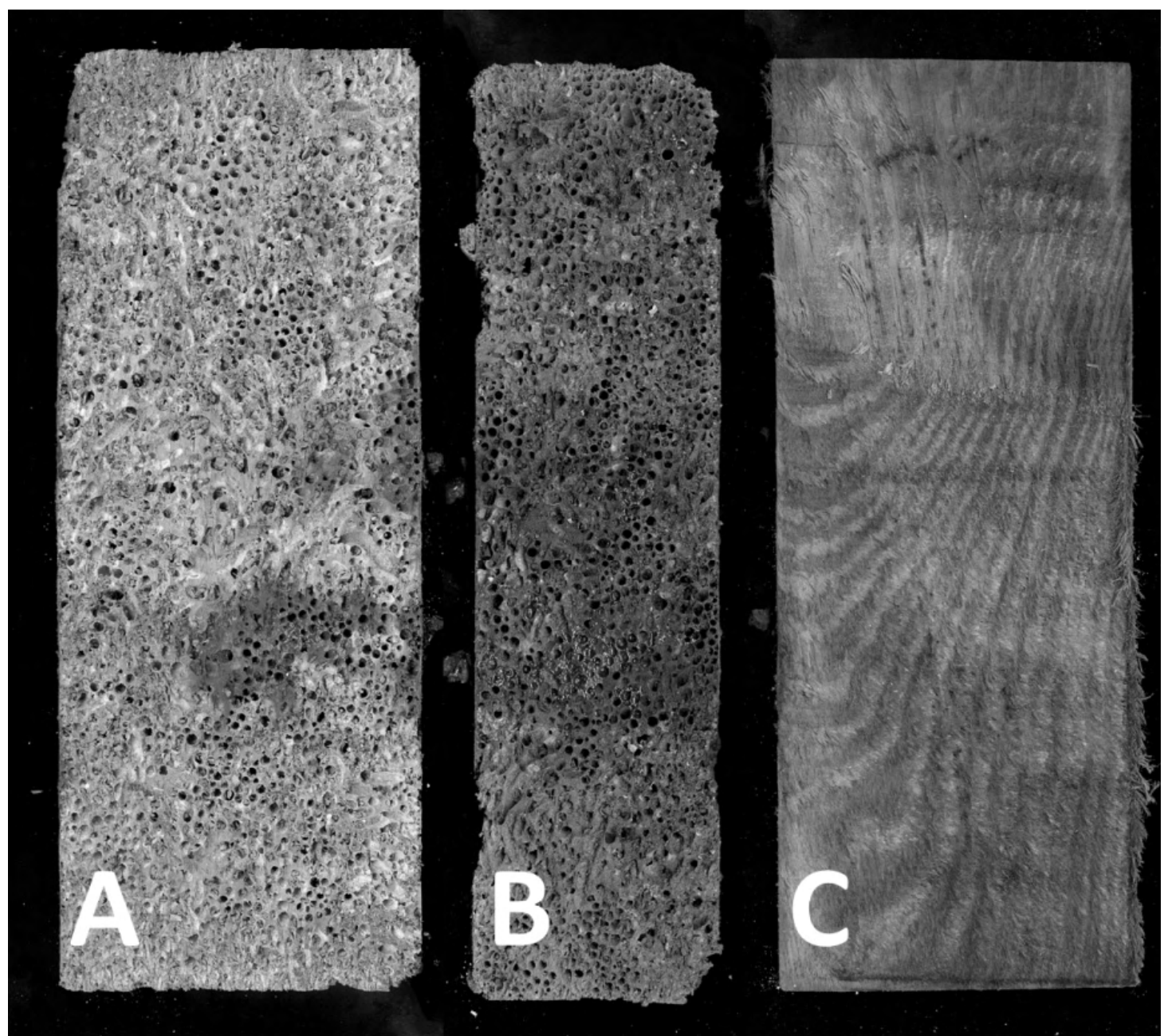

Figure 2 Cross-sections of specimens exposed in the Port of Koper: (A) untreated Scots pine sapwood and (B) untreated sweet chestnut heartwood exposed for 10 months; (C) Scots pine sapwood impregnated with Silvanolin $\mathrm{C}\left(c_{\mathrm{Cu}}=1.25 \%\right)$ exposed for 32 months

Slika 2. Poprečni presjek uzoraka izlaganih u luci Koper: (A) nezaštićeno drvo bjeljike bora i (B) nezaštićeno drvo srži kestena nakon 10 mjeseci izlaganja; (C) drvo bjeljike bora impregnirano Silvanolinom $\mathrm{C}\left(c_{\mathrm{Cu}}=1,25 \%\right)$ nakon 32 mjeseca izlaganja morskoj vodi

Table 3 Decay of Scots pine sapwood impregnated with commercial copper-ethanolamine solutions of different concentrations, after 18 months and 32 months of exposure in seawater of the Port of Koper, determined according to EN 275 (2004) Tablica 3. Propadanje drva bjeljike bora impregniranoga komercijalnom otopinom bakar-etanolamina različitih koncentracija, nakon 18 mjeseci i 32 mjeseca izlaganja utjecaju morske vode u luci Koper; sukladno normi EN 275 (2004)

\begin{tabular}{|c|c|c|c|c|c|c|c|}
\hline \multirow{2}{*}{$\begin{array}{l}\text { Preservative } \\
\text { solution } \\
\text { Otopina } \\
\text { zaštitnog } \\
\text { sredstva }\end{array}$} & \multirow{2}{*}{$\begin{array}{c}\boldsymbol{c}_{\mathrm{Cu}} \text { in preserva- } \\
\text { tive solution } \\
\text { Koncentracija } \\
\text { bakra u zaštitnom } \\
\text { sredstvu } \\
\% \\
\end{array}$} & \multicolumn{3}{|c|}{$\begin{array}{c}\text { Mean rating of deterioration after } 18 \\
\text { months of exposure } \\
\text { Srednja ocjena propadanja uzoraka } \\
\text { nakon } 18 \text { mjeseci izlaganja } \\
\end{array}$} & \multicolumn{3}{|c|}{$\begin{array}{l}\text { Mean rating of deterioration after } \\
32 \text { months of exposure } \\
\text { Srednja ocjena propadanja uzoraka } \\
\text { nakon } 32 \text { mjeseca izlaganja } \\
\end{array}$} \\
\hline & & Teredo & Limnoria & $\begin{array}{c}\text { Total } \\
\text { Ukupno }\end{array}$ & Teredo & Limnoria & $\begin{array}{c}\text { Total } \\
\text { Ukupno } \\
\end{array}$ \\
\hline Control & 0 & 4 & 1.6 & 4 & / & I & I \\
\hline CC & 1.2 & 0 & 0 & 0 & 0 & 0 & 0 \\
\hline CC & 5 & 0 & 0 & 0 & 0 & 0 & 0 \\
\hline Silvanolin A & 0.31 & 2 & 0.7 & 2 & 3 & 0.5 & 3 \\
\hline Silvanolin B & 0.625 & 0 & 0 & 0 & 1 & 0 & 1 \\
\hline Silvanolin C & 1.25 & 0 & 0 & 0 & 0 & 0 & 0 \\
\hline Silvanolin D & 2.5 & 0 & 0 & 0 & 0 & 0 & 0 \\
\hline Silvanolin E & 4 & 0 & 0 & 0 & 0 & 0 & 0 \\
\hline
\end{tabular}



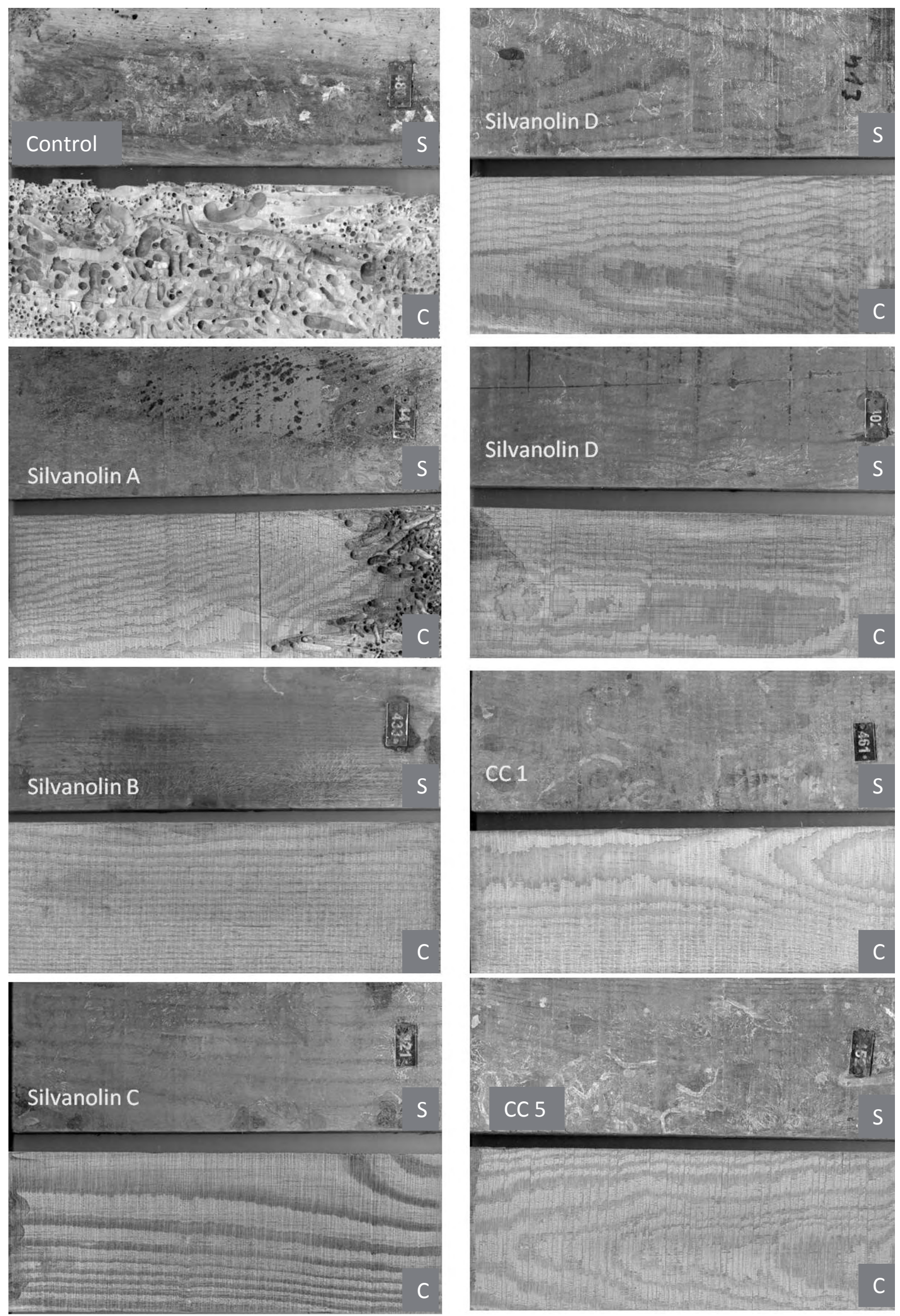

Figure 3 Surface $(S)$ and Cross-sections $(C)$ of copper treated specimens exposed in the Port of Koper, Slovenia for 18 months

Slika 3. Površina $(S)$ i poprečni presjeci $(C)$ uzoraka zaštićenih bakrom nakon 18 mjeseci izlaganja u luci Koper, Slovenija 
remained health even after 10 years of exposure in the North Sea.

If these results are compared to outdoor applications (use class 3 and 4), it is evident that almost ten to twenty times higher retentions are required in use class 5. For example field testing studies clearly showed that retention of $4 \mathrm{~kg} / \mathrm{m}^{3}$ of Silvanolin (Silvanolin A) was enough to ensure the service life of at least 7 years in above ground applications (Humar and Thaler, 2012).

\section{CONCLUSIONS}

\section{ZAKLJUČCI}

Wood in the northern Adriatic Sea is endangered by marine borers. Untreated controls of Scots pine sapwood and naturally durable heartwood of European oak, European larch and sweet chestnut were completely degraded in 10 months of exposure. On the other hand, impregnation of wood with copper-ethanolamine solution ensures good protection against marine borers if sufficient concentrations are applied.

\section{Acknowledgments - Zahvala}

Authors would like to acknowledge the Slovenian Research Agency for financial support in the framework of the program P4-0015-0481 and project V41139-0481. Generous support of the Port of Koper and mr. Andrej Pučko is appreciated as well.

\section{REFERENCES}

\section{LITERATURA}

1. Connell, M., 2004: Issues facing preservative suppliers in changing market for treated wood. Brussels: COST E22.

2. Cooper, P. A.; Ung, Y. T., 2009: Effect of preservative type and natural weathering on preservative gradients in southern pine lumber. Wood and Fiber Science. 41 (3): 229-235.

3. Cragg, S. M., 1989: Exposure trial at tropical marine sites of pyrethroid/creosote mixtures as wood preservatives: Preliminary results. Stockholm: The International Research Group on Wood Protection. IRG/WP 89-4155.

4. Cragg, S. M.; Pitman, A. J.; Henderson, S. M., 1999: Developments in the understanding of the biology of marine wood boring crustaceans and in methods of controlling them. International Biodeterioration and Biodegradation. 43: 197-205.

5. Despot, R.; Hasan, M.; Jug, M.; Šefc, B., 2008: Biological durability of wood modified by citric acid. Drvna industrija, 59 (2): 55-59.

6. Eaton, R. A.; Hale, M. D. C., 1993: Wood - decay, pests and protection. London: Chapman and Hall.

7. Humar, M.; Petrič, M.; Pohleven, F., 2001: Leaching of copper from wood treated with copper based wood preservatives. Drvna industrija, 52 (3): 111-116.

8. Humar, M.; Pohleven, F., 2008: Solution for wood preservation: EP 1791682. München: European Patent Office.

9. Humar, M.; Thaler, N., 2012: Performance of the copper treated and naturally durable wood in laboratory and out- door conditions. In: Grbac, I. (Ed.). Wood is good - with knowledge and technology to a competitive forestry and wood technology sector: proceedings: $23^{\text {rd }}$ international scientific conference, Zagreb, $12^{\text {th }}$ October 2012. Zagreb: Faculty of Forestry: pp. 33-40.

10. Kiersgaard, M., 2011: Teredo navalis E Limnoria - The anti Teredo System- a short introduction http://web.tiscali.it/matteopinto/English.htm (8. 6. 2011)

11. Larsson-Brelid, P.; Westin, M., 2010: Biological degradation of acetylated wood after 18 years in ground contact and 10 years in marine water. Stockholm: The International Research Group on Wood Protection. IRG/WP 10-40522

12. Lesar, B.; Humar, M., 2011: Durability of wood impregnated with copper-amine based preservative solution exposed to marine borer: preliminary results. Les. 63 (8/9): 323-325.

13. Rejec Brancelj, I. 2011: Morje http://www.arso.gov.si/ vode/publikacije\%20in\%20poro\%C4\%8Dila/Vodno_ bogastvo_6morje.pdf (8. 6. 2011)

14. Sen, S.; Yalcin, M.; Sivrikaya, H.; Bakir, A. K., 2010: Fouling and boring organisms that deteriorate various European and tropical woods at Turkish seas. African journal of biotechnology. 9 (17): 2566-2573.

15. Westin, M.; Rapp, A. O.; Nilsson, T., 2004: Durability of pine modified by 9 different methods. Stockholm: The International Research Group on Wood Protection. IRG/ WP 04-40288.

16. Wilkinson, J. G., 1979: Industrial timber preservation. London: Associated Business Press.

17. Williams, J. R.; Cragg, S. M.; Borges, L. M. S.; Icely, J. D.; Sawyer, G. S., 2007: Marine exposure assessment in southern Portugal of the natural resistance of a number of lesser known species of tropical hardwoods to teredinid and limnoriid borers. Stockholm: The International Research Group on Wood Protection. IRG/WP 07-10614.

18. *** Biocidal Products Directive (98/8/EC) 1998: Official Journal of the European Communities. L 123: 1-63.

19. *** CEN European Committee for Standardization 1994: EN 350-1 Durability of wood and wood-based products - Natural durability of solid wood - Part 1: Guide to the principles of testing and classification of the natural durability of wood.

20. *** CEN European Committee for Standardization 2004: EN 275 Wood preservatives - Determination of the protective effectiveness against marine borers.

21. *** CEN European Committee for Standardization 2006: EN 335 Durability of wood and wood-based products Definition of use classes.

22. *** Commission Directive 2011/71/EU 2001: Amending Directive 98/8/EC of the European Parliament and of the Council to include creosote as an active substance in Annex I there to Biocidal Products Directive (98/8/EC). Official Journal of the European Communities. L 123: 1-63.

\section{Corresponding author:}

Professor MIHA HUMAR

University of Ljubljana

Biotechnical Faculty

Jamnikarjeva 101

SI-100 Ljubljana, SLOVENIA

e-mail: miha.humar@bf.uni-lj.si 